\title{
Hard Divorces Make Bad Law
}

\section{Lucinda Ferguson ${ }^{\bullet}$}

Matrimonial Causes Act 1973, s1 - contested application for a decree nisi - unreasonable behaviour - no fault divorce

The English law on divorce is 'no fault' and turns solely on whether the marriage has 'broken down irretrievably' (s1(1) Matrimonial Causes Act 1973). But the applicant must prove it by adducing one of five facts (s1(2)) - either fault-based ((a) adultery, (b) behaviour, (c) desertion for two years) or based on separation and no-fault ((d) two years with consent, (e) five years without consent). Section 1(2)(e) operates as the default option in the absence of either fault or consent.

In Owens v Owens [2017] EWCA Civ 182, the wife sought to rely on s1(2)(b) behaviour, and the husband defended her application. The parties married in 1978 and had two adult children. The wife originally sent the husband a draft petition in December 2012, but did not pursue this. At the time of that draft petition, she was having an on-off affair (Owens, para. 3). The parties separated in February 2015 (para. 3), and she filed the petition that commenced these proceedings in May 2015 (para. 4).

\footnotetext{
- Associate Professor of Family Law, University of Oxford; Tutorial Fellow in Law, Oriel College, Oxford; Associate Member, 1 King's Bench Walk.
} 
The wife's petition included four complaints: firstly, the husband's inflexible prioritisation of work over family; secondly, making the wife feel unappreciated by not showing love and not supporting her role as homemaker and mother; thirdly, suffering from mood swings, which caused frequent arguments that the wife found distressing and hurtful; and, fourthly, being unpleasant and disparaging about the wife to family and friends, as well as being critical and undermining to and about her in front of family and friends, which made her feel upset and embarrassed (para. 4). The wife specified 9 particular incidents under the third complaint and 18 under the fourth (para. 6). At trial, His Honour Judge Tolson QC invited focus on the top ranking of the 27 allegations (paras. 8-11), particularly those that suggested embarrassing the wife in front of others (para. 20).

Judge Tolson found that as a matter of fact the marriage had broken down (para. 1), but refused to grant the wife a decree nisi on the basis that she had not proven s1(2)(b) MCA 1973. He saw the third and fourth complaints as the only potential basis to support the wife's petition, but considered her case 'hopeless', 'anodyne', 'scraping the barrel', 'lack[ing] beef because there was none' (para. 42) and the various allegations 'at best flimsy' (para. 46). In sum, 'all [of the allegations are] at most minor altercations of a kind to be expected in a marriage. Some are not even that' (para. 46). In reaching this conclusion, he applied an objective test with subject elements: 'would any right-thinking person come to the conclusion that this wife cannot reasonably be expected to live with him taking into account the whole of the circumstances and the characters and personalities of the parties?' (para. 45).

The wife appealed on two grounds: failure to apply the current law; and breach of Articles 8 and 12 of the European Convention on Human Rights (paras. 54-55). The Court of Appeal unanimously dismissed the wife's appeal. Munby P gave the lead judgment; Hallett LJ gave a shorter, concurring judgment; and Macur LJ agreed with both. 
Citing Cretney (2003: p. 391), Munby P poses the 'profoundly important point of principle and public policy' at stake: 'ought the decision whether or not a marriage should be dissolved to be one for the parties which the State is not in a position to question?' (para. 90). That the Owens' case is before the court, however, suggests a different question: where a marriage has broken down as a matter of fact, ought one party's experience of the marriage to be sufficient to hold that it has also broken down as a matter of law, without the significance of that experience being vulnerable to challenge by either the other party or the State?

Munby P reasons that he neither needs nor intends to add to the jurisprudence (para. 37). He agrees with earlier decisions (discussed at paras. 27-34) that the test is that set out in the current edition of Rayden and Jackson on Relationship Breakdown, Finances, and Children (para. 35):

6.82 The words 'reasonably be expected' in the statute prima facie suggest an objective test. Nevertheless, in considering what is reasonable, the court (in accordance with its duty to inquire, so far as it reasonably can, into the facts alleged) will have regard to the history of the marriage and to the individual spouses before it in assessing what is reasonable.

The cited paragraphs $6.83-6.85,6.86$, and 6.88 of Rayden and Jackson also repay careful attention, the final of which notes that the court will have regard to the cumulative effect of the conduct, as Munby $\mathrm{P}$ also restates (para. 37). This objective test is interpreted according to the standards of 'the man or woman on the Boris Bus with their Oyster Card in 2017' (para. 41). Viewing Judge Tolson's decision in light of this test, Munby P does not consider that it was plainly wrong. Judge Tolson was entitled to evaluate the facts as he did and for the reasons he gave, and he made no error of law or procedure in focusing examination on particular allegations (para. 74). 'Parliament has decreed', Munby P concludes, 'that it is not a ground for divorce that you find yourself in a wretchedly unhappy marriage...' (para. 84).

The wife's subsidiary Convention argument was rejected on the 'irrefutable' basis that there is neither a Convention right to divorce nor, in jurisdictions in which divorce is 
permitted, a Convention right to a favourable outcome in divorce proceedings (Munby P: para. 77). Munby P sees Babiarz v Poland (Application no. 1955/10) (10 January 2017) as 'determinative' on this point (para. 56).

Setting aside the issue whether the law is 'badly out-of-date, indeed antediluvian' which, Munby P comments, it 'may be' (para. 38), the Court of Appeal's decision seems correct on the current law. But there are two reasons why it is not at all clear that the modern London commuter would have made the same decision as Judge Tolson. Firstly, reporting interim findings on divorce in practice, Trinder concludes that the threshold for s1(2)(b) petitions 'appears to be lower than 30 years ago' (2017: p. 1), which accords with Hallett LJ 'accept[ing] that concepts of unreasonable behaviour may change over time' (para. 100)

Secondly, as Hallett LJ reasons (para. 100), and Munby P agrees (para. 37), 'behaviour considered trivial in the context of a happy marriage may assume much greater significance for a husband or wife trapped in an unhappy marriage'. The public response to the decisions at both levels in Owens - noted by Munby P (para. 53) - suggests that the modern London commuter may well have concluded that, taking account of the subjective specifics of the very unhappy marriage, the husband's behaviour was objectively unreasonable. To reach this conclusion would certainly be an act of kindness to the wife. As Eekelaar reasons, '[w]here [love] has failed, it cannot be brought back to life by the legal process, but acts of kindness can persist' (2016: p. 301). I agree with the Court of Appeal, however, that a decision to the contrary is not plainly wrong.

In terms of the consequences of this decision, Owens may raise the threshold for meeting s1(2)(b) in practice, at least in the immediate future. Owens is necessarily concerned with specific facts and, as noted, there are subjective elements within the objective test. But, as Munby P 'cannot help thinking that, if the husband had not sought to defend, the petition would have gone through under the special procedure without any thought of challenge from 
the court,' (para. 93) it suggests that, in uncontested applications, future District Judges or Legal Advisers may be less inclined to accept that the facts as pleaded satisfy s1(2)(b).

Whilst it may be argued that taking the threshold seriously would in fact rectify ' $[t]$ he hypocrisy and lack of intellectual honesty which is so characteristic a feature of the current law and procedure' (para. 94), we need to ask where the public interest lies in refusing petitions. That is not to justify the 'consensual, collusive, manipulation' of s1(2)(b) (para. 94), but to highlight that any public policy argument here must be expressive, not substantive. If it were substantive, we could not explain our modern history of overlooking collusive divorce by consent. In expressive terms, it is not at all clear why we should assume that the difficulty of access to divorce is in a linear relationship with the significance of marriage as an institution. This conclusion is supported by Trinder finding no evidence that the current law protects marriage (2017: p. 1).

If, as Munby P (paras. 92-98) and Hallett LJ (para. 99) imply, the decision in Owens evidences the unsatisfactory nature of the law on divorce, how should it be reformed? Introducing unilateral divorce on demand would arguably be unacceptable because of the vulnerable position in which it would place the other party. Conversely, the current system may also distort bargaining positions as it places the person who does not want to divorce in a position to extract concessions in relation to children and finances against the threat of the five-year long stop (Lord Chancellor's Department, 1995: para. 2.30). This contrast highlights the need for well-conceived reform that protects both parties. Introducing divorce by consent as an additional alternative within the current framework - as contemplated by the private member's No Fault Divorce Bill 77 (2015-16) - would not necessarily reduce the incentive to collude; the Bill, for example, requires a one-year cooling-off period between decree nisi and decree absolute. What of comprehensive reform to introduce true 'no fault' divorce, which entails removing all facts? Resolution has recently advocated this approach 
(2016). In addition to a six-month cooling-off period, however, Resolution envisages

unilateral divorce but does not specify how the scheme intends to protect vulnerable parties' interests.

The move to online divorce, and the concomitant need for administratively workable processes, will arguably increase the pressure to move away from the fault-based facts and the possibility of contested petitions. Divorce reform driven by pragmatism may well be more likely to succeed than the Family Law Act 1996, Part II. As for Mrs Owens, she intends to seek permission to appeal to the Supreme Court. If granted, it will be interesting to see how the panel regards the modern London commuter's view of incidents within a 'wretchedly unhappy marriage' (para. 84).

\section{References}

Cretney, S. (2003). Family Law in the Twentieth Century, Oxford: Oxford University Press.

Eekelaar, J. (2016). 'Family law and love', Child and Family Law Quarterly, 28, 289-301.

Lord Chancellor's Department. (1995). Looking to the future: Mediation and the ground for divorceThe Government's Proposals, Cm 2799, London: HMSO.

Resolution. (2016). 'No fault divorce: End the blame game', online: http://www.resolution.org.uk/endtheblamegame/ (5 April 2017).

Trinder, E. (2017). 'Finding Fault?' Interim research findings, University of Exeter, online: findingfault.org.uk/wp-content/uploads/2017/03/Finding-Fault-interim-research-findings.pdf (24 March 2017). 